\title{
Neurogenesis After Stroke: A Therapeutic Perspective
}

\author{
Abir A. Rahman $^{1}$ (D) $\cdot$ Narayanappa Amruta $^{1}$ (D) $\cdot$ Emmanuel Pinteaux ${ }^{2}$ (D) $\cdot$ Gregory J. Bix ${ }^{1,3}$ (D)
}

Received: 30 June 2020 /Revised: 14 August 2020 / Accepted: 17 August 2020 / Published online: 29 August 2020

(C) The Author(s) 2020

\begin{abstract}
Stroke is a major cause of death and disability worldwide. Yet therapeutic strategies available to treat stroke are very limited. There is an urgent need to develop novel therapeutics that can effectively facilitate functional recovery. The injury that results from stroke is known to induce neurogenesis in penumbra of the infarct region. There is considerable interest in harnessing this response for therapeutic purposes. This review summarizes what is currently known about stroke-induced neurogenesis and the factors that have been identified to regulate it. Additionally, some key studies in this field have been highlighted and their implications on future of stroke therapy have been discussed. There is a complex interplay between neuroinflammation and neurogenesis that dictates stroke outcome and possibly recovery. This highlights the need for a better understanding of the neuroinflammatory process and how it affects neurogenesis, as well as the need to identify new mechanisms and potential modulators. Neuroinflammatory processes and their impact on post-stroke repair have therefore also been discussed.
\end{abstract}

Keywords Stroke $\cdot$ Neurogenesis $\cdot$ Neuroinflammation $\cdot$ Cytokines $\cdot$ Stroke therapy

\section{Introduction}

Stroke is a debilitating disease condition defined as either an interruption of blood supply to the brain due to a clot or embolism, or the rupture of a blood vessel in the brain, which then leads to neurological impairments [1]. It remains the 3rd leading cause of death worldwide, with nearly 15 million people being affected every year [2], while in the USA, it is the number 5 killer, killing nearly 140,000 people every year (https://www.cdc.gov/stroke/facts.htm). Currently, the treatment for ischemic stroke is to administer a thrombolytic agent such as tissue Plasminogen Activator (tPA) or to perform a surgical thrombectomy procedure to mechanically

Abir A. Rahman and Narayanappa Amruta contributed equally to this article.

Gregory J. Bix

gbix@tulane.edu

1 Clinical Neuroscience Research Center, Department of Neurosurgery, Tulane University School of Medicine, Room 1349, 131 S. Robertson, Ste 1300, New Orleans, LA 70112, USA

2 Faculty of Biology, Medicine and Health, University of Manchester, A.V. Hill Building, Oxford Road, Manchester M13 9PT, UK

3 Tulane Brain Institute, Tulane University, New Orleans, LA 70112, USA remove the blood clot (thrombus) [3]. However, the optimal time window for these treatments is very small and survivors often exhibit a high degree of morbidity, as well as limited functional recovery [4]. New modes of therapy are therefore urgently needed, especially ones that can be administered after longer periods following stroke onset, that can lead to better functional recovery and reduced morbidity. To this end, poststroke brain repair processes are of particular research interest. Here, in this review, we discuss stroke-induced neurogenesis as a potential target for therapeutic intervention, as it represents a major repair mechanism that by itself falls short in achieving full recovery in surviving patients, and presumably could be modulated to achieve better outcomes. A detailed understanding of this phenomenon is needed to guide future research and the development of effective intervention strategies.

\section{Neurogenesis in the Post-stroke Brain}

Neurogenesis, or the birth of new neurons, is known to be induced in response to ischemic stroke, in the infarct and surrounding areas. Neural stem cells originating from the sub-ventricular zone (SVZ) and the sub-granular zone of the dentate gyrus are considered to give rise to these new neurons [5-7]. This is thought to be a key process in post-stroke 
recovery and repair of the damaged brain region [8-10]. In general, this involves the migration of neural stem cells to the infarct and peri-infarct region, followed by their differentiation into functional neurons [11-13]. This process is schematically depicted in Fig. 1, based on information derived from research in rodents and other model systems. An important factor to consider in post-stroke functional recovery is the ultimate survival of these newborn neurons. Several studies have reported their reduced survivability possibly due to their microenvironment lacking trophic factors as well as chronic inflammatory responses [14-16]. Acute neuroinflammation, however, has been reported to promote neurogenesis and may be promoting neuronal survival as well $[17,18]$. In addition, age remains a prominent factor affecting neurogenesis. The rate of neurogenesis steadily declines with rising age, with stroke increasing the sharpness of that decline $[8,19$, 20]. Notably, Darsalia and collaborators [8] reported that striatal neurogenesis after stroke is similar in young and aged mice, while hippocampal neurogenesis is impaired in aged animals compared with the young animals. This raises the possibility of differential region-specific regulation mechanisms and multiple modulatory opportunities if the mechanisms could be harnessed.

\section{Factors Governing Neurogenesis}

The process of neurogenesis can generally be categorized into three stages: (1) neural stem cell proliferation, (2) migration of neuroblasts and immature neurons, and (3) differentiation into mature neurons and neurite extension, finally leading to synaptogenesis and stabilization of the synapses. There are a number of molecules that affect one or more of these stages, and they differ between embryonic neurogenesis and adult neurogenesis [21-23]. We will focus on some that have been identified as important for stroke-induced neurogenesis.

Ruan and collaborator in a recent review [24] mention Fibroblast growth factor-2 (FGF-2) [25, 26], Insulin-like Growth Factor-1 (IGF-1) [27, 28], Brain-Derived Neurotrophic Factor (BDNF) [29-31], and Vascular Endothelial Growth Factor (VEGF) [32] as factors that directly affect neural stem cell proliferation, while identifying Stromal-derived factor (SDF-1), Monocyte Chemoattractant Protein (MCP-1), and Matrix metalloproteinases (MMP) 2, 3 , and 9 as factors influencing neuroblast migration [33-36]. SDF-1 and MCP-1 are both chemokines that form part of the inflammatory response to the ischemic injury [37, 38], whereas MMPs are matrix metalloproteinases involved in remodeling of the extracellular matrix [35]. Remodeling of the matrix often occurs to allow reparative processes like angiogenesis to take place [39]. In this case, however, the remodeling may be taking place in part to allow the migrating neuroblasts to pass through. In addition, proteolysis of matrix proteins such as perlecan has been implicated in promoting neurogenesis in post-stroke brains [40]. Its c-terminal domain $\mathrm{V}(\mathrm{DV})$ is thought to be the active component leading to neurogenesis as well as angiogenesis at the infarct and peri-infarct area [41, 42]. Using neurospheres and fetal cortical neurons in vitro, Trout and colleagues [42] showed that perlecan DV also promoted differentiation into mature neurons as well as neurite

\section{a}

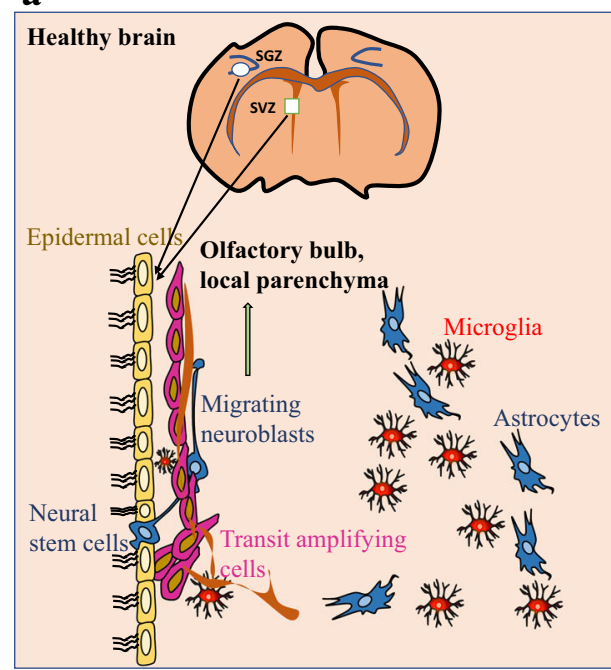

Fig. 1 Schematic representation of adult neurogenesis in rodents. a Healthy brains: Neural stem cells proliferate from the SVZ and SGZ form neuroblasts that migrate to the olfactory bulb and local parenchyma. b Stroke brains: There is pronounced loss of striatal and cortical neurons, giving rise to increased proliferation of progenitors. b

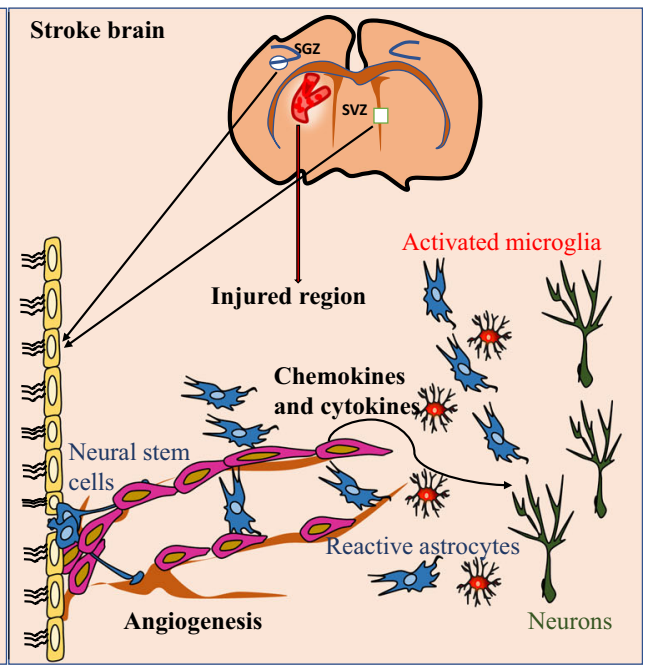

The neuroblasts formed before and after the stroke migrate to the site of injury, influenced by chemokines and cytokines secreted by resident and activated microglia, reactive astrocytes, etc. The neuroblasts then differentiate into newborn neurons coupled with angiogenesis at the site of injury, giving rise to mature neurons 
extension. In this way, the MMPs may be serving a dual function.

\section{Neuroinflammation and Neurogenesis}

For the most part, the dogma is that neuroinflammation and neurogenesis are inversely related. Factors like Sirtuin 7, Glucagon-Like Peptide-1, and Nei like DNA Glycosylase 1 enhance neurogenesis by suppressing neuroinflammation [43-45]. Inhibition of Glycogen Synthase Kinase-3 (GSK-3) has also been shown to increase neurogenesis, while reducing neuroinflammation, implicating Wnt signaling in the process [46-48]. However, depending on the timing, duration, and the profile of cytokines and chemokines released, neurogenesis could be positively impacted [17, 18, 49-51].

An example of how the duration of inflammation can be an important factor is seen by the effect of interleukin-6 (IL-6) on neurogenesis. Short-term treatment of neural stem cells with a hyperactive fusion IL-6 protein induces neurogenesis in vitro [49], while chronic astrocytic IL-6 transgene expression led to reduced neurogenesis in the dentate gyrus of the transgenic mice [20]. Similarly, interleukin $1 \alpha(\mathrm{IL}-1 \alpha)$ and interleukin$1 \beta$ (IL-1 $\beta$ ) follow an out of phase expression pattern in response to ischemia, where IL- $1 \alpha$ expression occurs early following ischemia whereas IL- $1 \beta$ is expressed much later and coincides with reduced IL- $1 \alpha$ production, indicating that the two cytokines likely have different roles during the poststroke neuroinflammatory response $[52,53]$. Indeed, IL- $1 \alpha$ is reported to be neurogenic [17] and gliogenic [54], while IL-1 $\beta$ is primarily thought to induce neural death and clearance of dead cells and debris [55-57]. One of the ways interleukin-1 (IL-1) potentially regulates neurogenesis is by driving the expression of pentraxin 3 (PTX-3). This protein is a known biomarker for cerebrovascular diseases and plays a key role in maintaining blood-brain barrier (BBB) integrity. While one study identified IL- 1 as a driving regulator of PTX3 [58], a second follow-up study reported the neurogenic ability of PTX-3, inducing IL- $1 \beta$-dependent proliferation in neurospheres [59]. In the latter study, PTX3 knockout mice also exhibited reduced proliferating stem cell population in the dentate gyrus after MCAO, further supporting the idea that PTX-3 induces neurogenesis.

Among the various cells involved in mediating inflammation in the brain, microglia are of particular interest as a cell type that can infer both neuroprotection and neuronal death. How they affect neurogenesis has been a major focus of many studies. Microglia have been reported to produce trophic factors to guide and support neural stem cell migration and differentiation, but also, on other occasions, produce cytokines that hamper cell survival [60-64]. When microglia in the brain were nearly completely depleted by administration of the Colony-stimulating factor 1 receptor (CSF1R) antagonist
PLX3397, the resulting mice exhibited approximately $60 \%$ increase in infarct size after MCAO [65], indicating the largely neuroprotective role played by microglia. In a quiescent and ramified state, microglia tend to secrete trophic factors that support surrounding neurons, whereas in a more activated (ameboid) state, they tend to eliminate neurons. The CX3C Receptor 1, expressed by microglia, has been shown to play a key role in the modulation of these characteristics. Its inhibition leads to reduced hippocampal neurogenesis leaving the olfactory bulb unchanged $[66,67]$.

In addition to microglia, astrocytes have also been shown to influence neurogenesis, particularly reactive astrocytes $[68$, 69]. Traditionally, they were thought to contribute more to neuronal apoptosis than neuronal survival in the ischemic brain [70]. However, recent studies have informed more about their robust neurogenic properties. In addition to secreting growth and other factors to strengthen synapses, some astrocytes act as neuronal precursors [71-73]. These cells can not only differentiate into mature neurons but are also able to divide asymmetrically to generate a neuron and another precursor [73]. There are ongoing efforts to exploit these properties clinically, especially in conjunction with stem cell-based approaches [74]. Faiz and colleagues (2015) have identified Ascl1 as a gene that can induce the transdifferentiation of astrocytes into neurons [75]. Similarly, Zhang et al. (2018) have implicated IL-17 expression and release from astrocytes in promoting neurogenesis via the NF-KB pathway [76]. Another study reported that the secretion of $\beta$-arrestin from astrocytes promoted neurogenesis, while knockout animals displayed reduced proliferation of neural precursor cells [77]. Disrupted in Schizophrenia 1 (DISC-1) is yet another gene expressed by astrocytes known to influence neurogenesis, where a dominant negative mutation is known to cause reduced neurogenesis [78]. Astrocytes, therefore, present an attractive target for stroke therapy, especially when combined with stem cell-based therapeutic approaches and other neurogenesis promoting treatments. If the developmental ability of astrocytes to neurons can be harnessed and modulated, this presents a somewhat renewable pool of neural precursors, which is additional to neuroblasts from the SVZ and the DG. Furthermore, astrocyte-derived growth and support factors can also be clinically targeted to ensure better survival of the post-stroke newborn neurons.

\section{Targeting Neurogenesis in Experimental Stroke}

Regarding modulating post-stroke neurogenesis to improve stroke outcome, there are a number of considerations. Selective ablation of post-stroke neurogenesis has been reported to have deleterious effects in stroke recovery [79-81], indicating the potential for manipulating neurogenesis to alter 
stroke outcome. This is further reinforced by studies showing enhancement of neurogenesis positively affecting stroke outcome [82-85]. In doing these studies, the timing of intervention becomes a key consideration because neurogenesis is a part of the delayed repair process and any intervention targeting an aspect of the neurogenic process needs to be in synchrony for maximum efficacy [86-88]. In addition, it is important to consider the interplay with other repair processes such as angiogenesis [24]. Some recent studies examining post-stroke neurogenesis are listed in Table 1.

In early studies, newborn neurons were detected in gerbil brains after cerebral ischemia, 26 days after ischemic insult and persisted for 7 months [89]. More recent studies, however, showed that in mice and rats, neural stem cell proliferation in the SVZ was significantly enhanced in as early as the first 714 days after MCAO [11, 13, 90, 91]. Thored and colleagues reported the presence of neuroblasts from 1 week up to 16 weeks after insult, in the striatum [7]. Similarly, neuroblasts were shown to migrate to the cortex and survive for 35 weeks or more [90]. Therefore, these represent the rodent counterparts for therapeutic windows for treatments aimed at proliferation (7 days and beyond) and migration. These time windows would be different in humans and need to be investigated to determine effective treatment regimes. Lastly, most of these neurons die within 2-5 weeks [15]. It is this critical period that must be targeted if neuroprotective factors or factors promoting neuronal survival are to be administered for therapy, although it is unclear how long that treatment will have to be continued, to ensure the survival of the newborn neurons. It may be important to target the process of synaptogenesis at time periods like this since failure to make connections has been proposed as a mechanism of neuronal death [15].

The process of angiogenesis has been reported to be closely intertwined with the process of neurogenesis after stroke [24, $85,92-95]$. This process is defined as the formation of new blood vessels via the sprouting of preexisting vessels and generally occurs in response to an injury such as cerebral ischemia [96]. It is characterized by proliferation of endothelial cells that then form tube-like structures, ultimately forming the complete blood vessel [97]. Research has shown that endothelial cells secrete a number of neurotrophic factors like VEGF, Angiopoeitin-1, and SDF-1 that facilitate neurogenesis and neuronal differentiation and subsequent survival [33, 98, 99]. Moreover, angiogenic processes precede the neurogenic processes in the infarct area after ischemic insult [100-103]. Research has also shown that modulation of the factors governing neurogenesis also affects angiogenesis [32, 104-108]. These all point to the idea that modulation of neurogenesis can be achieved by modulation of angiogenesis as well as the importance of keeping angiogenic processes in mind while manipulating neurogenesis. A question can be raised about how one could go about targeting neurogenesis specifically without altering angiogenesis. One way to do so may be to delay treatments such that period of angiogenesis is surpassed and mostly neurogenesis is targeted [17], while an alternate method could involve treating with a cocktail with components that would compensate for effects on angiogenesis specifically that might occur as a concurrent effect of one or more of the other components. It might have to be a combination of the two methods or others to achieve maximum targeting efficiency.

\section{Drugs Targeting Neuroinflammation to Alter Neurogenesis}

Minocycline is a tetracycline derivative that inhibits microglial activation and has been shown to be neuroprotective following focal cerebral ischemia $[109,110]$. It has also been shown to be able to upregulate neurogenesis in multiple models [111-113]. Therefore, this remains the most promising pharmacological agent in this regard. Srivastava and collaborators [114] reported it as safe and efficacious in their clinical trial, which was further supported by the metaanalysis conducted by Malhotra and colleagues [115], of seven randomized clinical trials. It is safe to be administered for sure, but its efficacy still needs some more validation before it is widely accepted for treatment of stroke.

Another study reported that the drug Sildenafil promoted neurogenesis and was able to enhance functional recovery after perinatal/pediatric ischemia in mice [116]. While this is not exactly the same as the hypoxia occurring during ischemic stroke, it is consistent with previous findings that sildenafil promotes neurogenesis after focal cerebral ischemia [117-119]. Engels and collaborators [116] proposed that Sildenafil altered the levels of Wnt signaling pathway members $\beta$-catenin and GSK-3, via inhibition of phosphodiesterase type 5 , and subsequent increase in cGMP levels. Although they did not find any direct evidence of affected neuroinflammation, GSK-3 and Wnt signaling has been implicated in the regulation of neuroinflammation in several studies [120,121]. One GSK inhibitor called Tideglusib has been investigated in clinical trials as well, where it was deemed clinically safe but was not effective $[122,123]$. Other GSK inhibitors that may be worth exploring include 6-bromoindirubin-30-oxime (BIO) $[46,48]$ and lithium chloride $[47,124]$.

Based on several in vitro and in vivo studies investigating the role of IL-1 in stroke, recent studies have considered IL-1 receptor antagonist (IL-1Ra) as an attractive new therapy. Indeed, a small phase 2 clinical trial showed that IL-1Ra is safe in stroke and may be effective [125], and the more recent SCIL-STROKE study confirmed this hypothesis that IL-1Ra may be potent neuroprotective therapy in stroke [126]. IL-1Ra may improve stroke outcome through inhibition of the inflammatory response; however, an interesting recent study found 


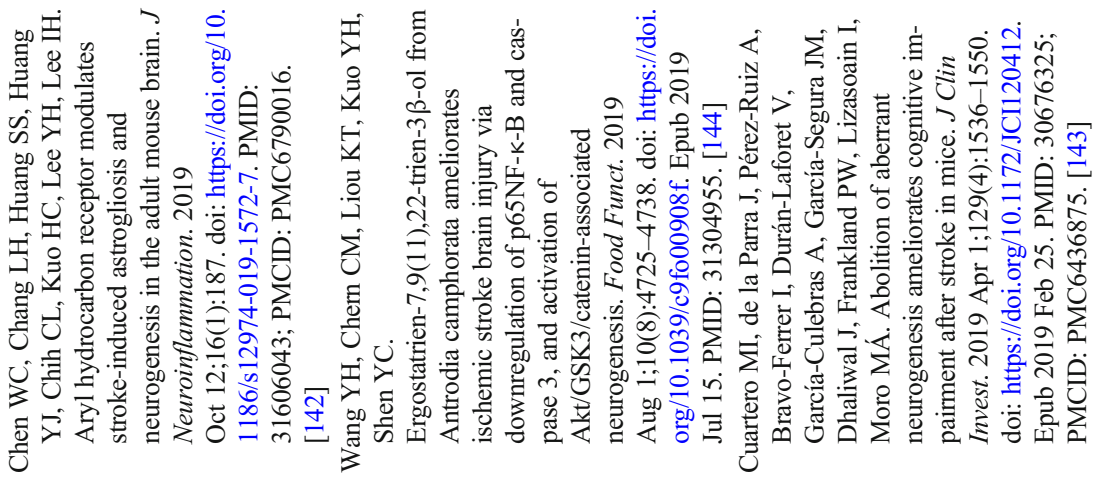

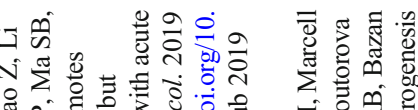

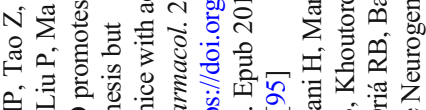

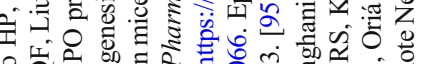

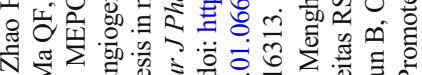

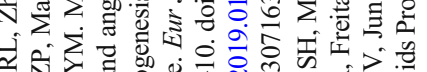

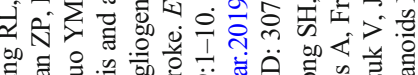

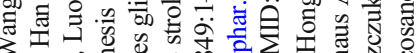

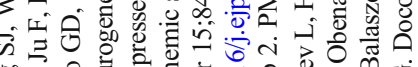

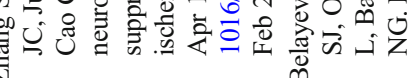
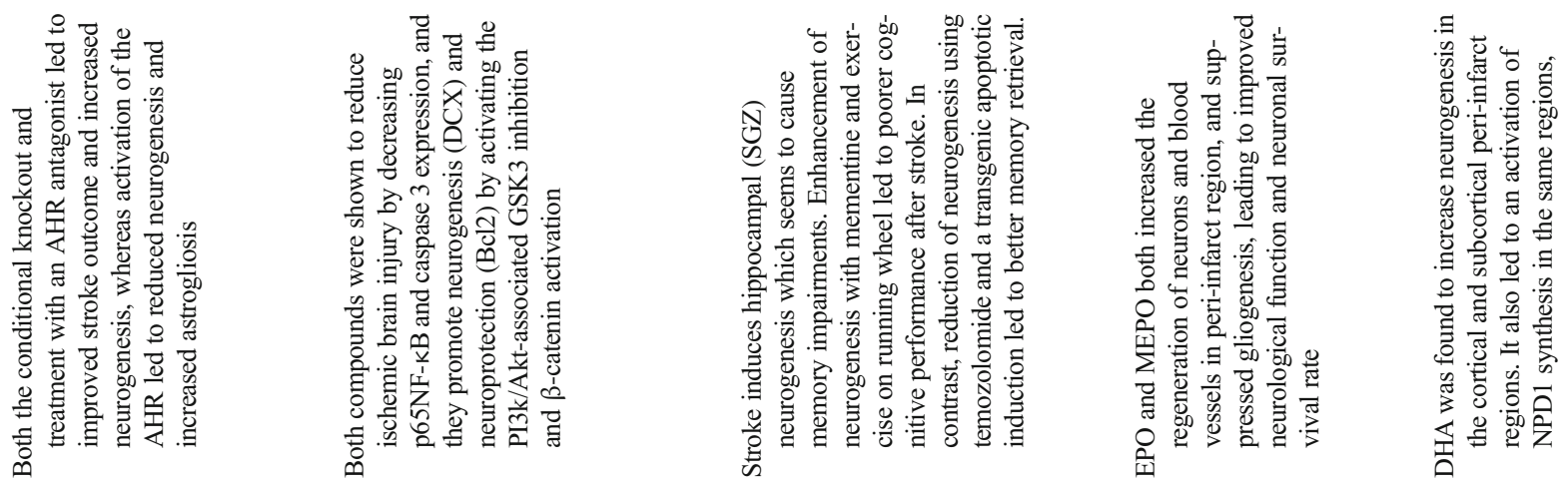

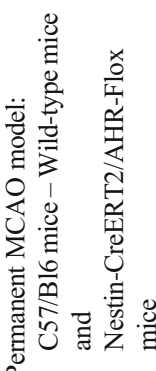

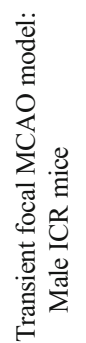
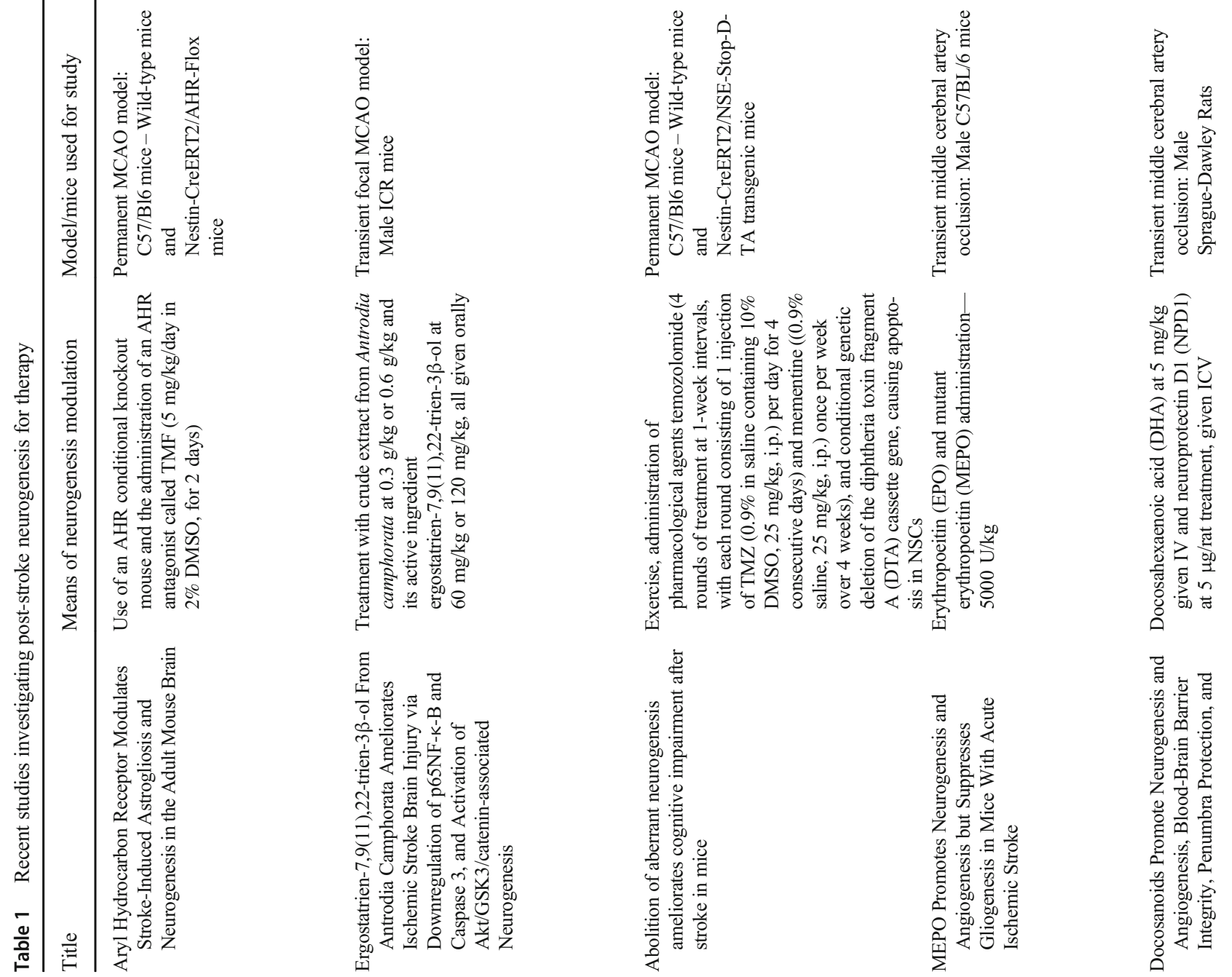


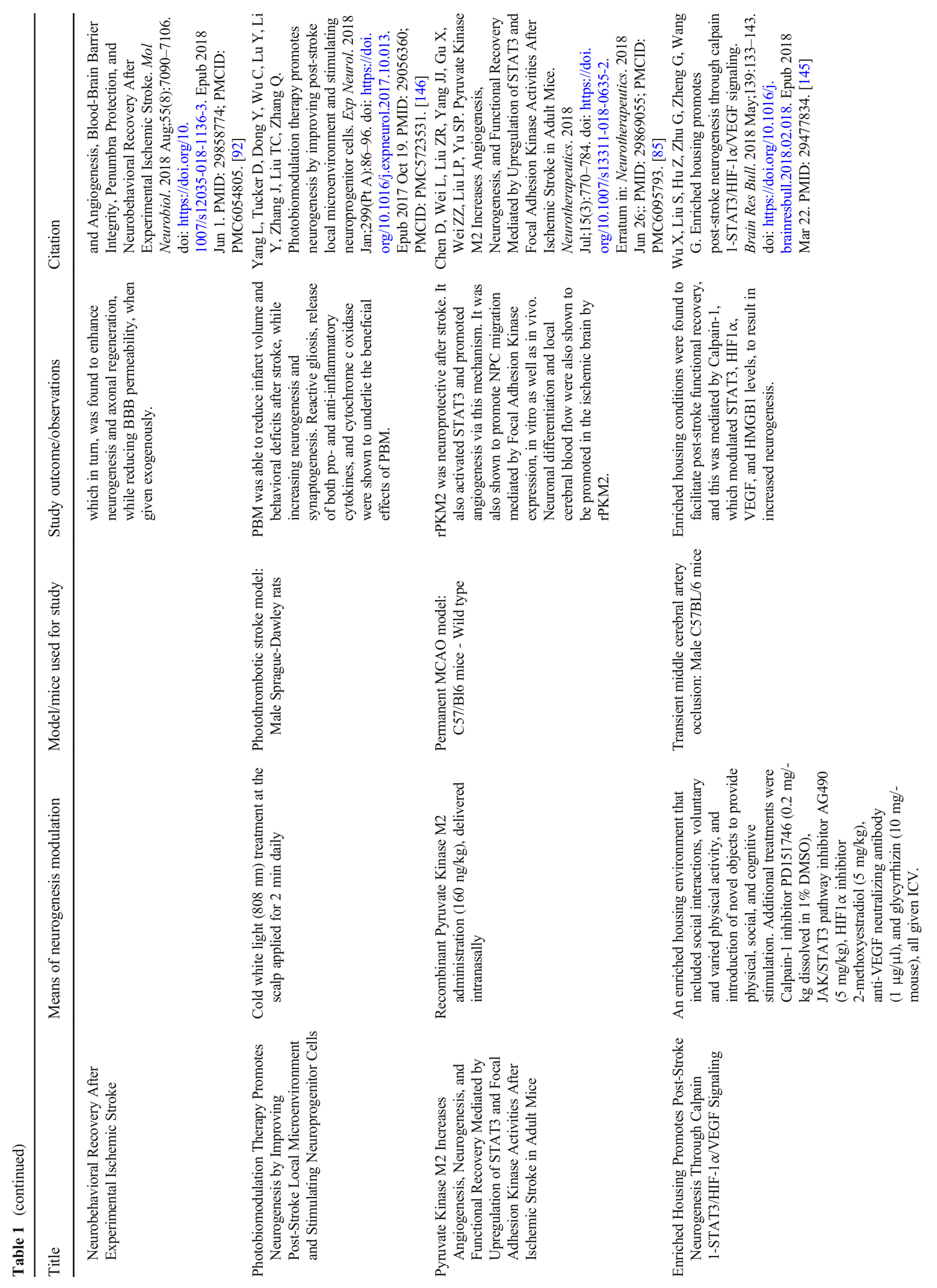




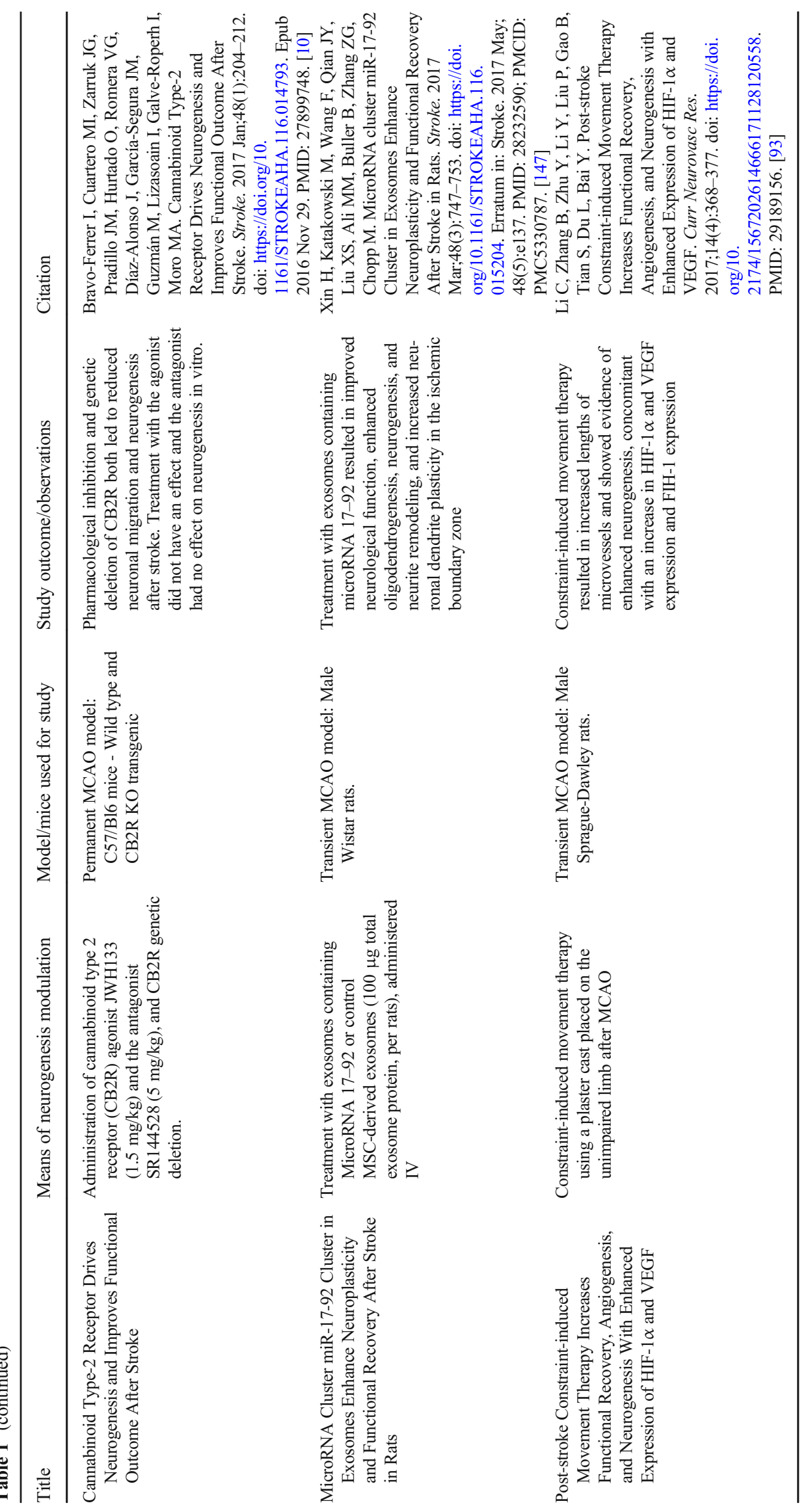


that IL-1Ra administration in rat stroke model potently promotes long-term neurogenesis and functional recovery [127]. This study suggests that, although acute inflammation is an important trigger for post-stroke neurogenesis, a more controlled neuroinflammatory response appears critical for an optimum neurogenic response after stroke. These are only a few of the drugs being tested for efficacy in stroke treatment, via neurogenesis modulation. It is widely recognized that pharmacological modulation of neurogenesis can be a valuable tool to treat stroke and is, therefore, likely to be active area of research focus for the foreseeable future.

\section{Potential of Stem Cell-Based Therapy and Considerations of Challenges}

One major observation in ischemia-induced neurogenesis is that only a small quantity of the newborn neurons survive in the peri-infarct area $[7,15]$. Therefore, to overcome this, in addition to modulating endogenous neurogenesis, stem cell therapy to treat stroke has also been investigated as a possible alternative or as a potential way to augment the endogenous stroke-induced neurogenesis [128-130].These exogenous stem cells can become the source of some much-needed trophic factors and exert paracrine reparative effects. In turn, this could lead to the microenvironment in the peri-infarct area more supportive of new neuron differentiation and integration into the circuitry.

In one study, transplanting human fetal neural stem cells into the hippocampus $24 \mathrm{~h}$ after surgically occluding the middle cerebral artery in mice was reported to have improved behavioral recovery and reduced infarct volume, compared with animals without the transplant [131]. They also noted improved BBB repair and lower number of activated microglia in the transplanted brains, as well as higher abundance of Brain derived neurotrophic factor (BDNF). A subsequent study by the same research group reported the transplant procedure as highly beneficial in combination with tissue plasminogen activator (t-PA) treatment, resulting in lower levels of pro-inflammatory cytokines, tumor necrosis factor (TNF- $\alpha$ ) and IL-6, as well as MMP-9 [129]. Taken together, these validate the potential of transplanting fetal neural stem cells as a mode of therapy. Of course, the ethical challenges of obtaining and maintaining such stem cells remain a major limitation of such a process.

The alternative approach to using fetal stem cells is to use inducible pluripotent stem cells (iPSCs) or mesenchymal stem cells (MSCs). Oki et al. [132] used human iPSC-derived neuroepithelial-like stem cells that they transplanted into mice 1 week and $48 \mathrm{~h}$ after MCAO. They reported improved forelimb motion recovery, increased VEG-F deposition, and successful differentiation of iPSCs into neurons in the striatum.
Use of MSCs is limited by the observation that most of the systemically transplanted MSCs end up in the lungs and do not make it to the infarct area of the brain [133, 134], where they are actually intended to proliferate and repair the damage. Tobin and colleagues [135] have proposed the use of MSCs that have been activated by Interferon gamma (aMSCs). They reported that both activated and naïve MSCs induced complete behavioral recovery, reduced infarct volumes, and reduced microglial activation and levels of IL- $1 \beta, \mathrm{TNF}-\alpha$, and IL-6 in treated animals, compared with vehicle-treated control stroke animals. However, they propose the activated MSCs are a better treatment option than naïve MSCs because of an increased yield of anti-inflammatory factors from microglia. Interestingly, they did not observe any induction of neurogenesis in the SVZ after MSC treatment.

A phase 1 clinical trial (PISCES) involving the administration of CTX0E03 human neural stem cells via stereotactic ipsilateral putamen injection reported that a dose of up to 20,000 cells is safe and well tolerated in patients [136]. The treatment also resulted in functional improvements and upon further investigation, may very well become a mainstream intervention strategy. Since the study was conducted only on 11 men, it needs to be followed up with the inclusion of female patients and a larger patient population [136].

Another phase 2 clinical trial involving the administration of bone marrow stem cells to stroke patients proved safe in patients, but ineffective in terms of treating stroke [137]. Similar results were obtained in another phase 2 clinical trial where patients were treated with bone marrow derived ALD401 stem cells [138]. Taken together, these studies indicate that the administration of stem cells is safe. As for effectiveness, there is potential for the stem cells to promote functional recovery in more tightly controlled settings, which was a limitation of all three studies, along with the small population of patients that have been tested.

The process of preconditioning the MSCs and using the resulting media may prove even more effective in stroke treatment $[128,139]$. A recent systemic review highlighted the therapeutic potential of extracellular vesicles secreted by various cells like MSCs, macrophages, and neural stem cells, identifying these vesicles as an attractive approach. However, being a recent trend, there is a significant amount of heterogeneity among the results of applications, presumably due to isolation and administration techniques, as well as cell-type of origin [140]. Further work on MSCs preconditioning with various inflammatory mediators found that IL- $1 \alpha$ can be used as a key priming stimulus to induce MSCs to produce anti-inflammatory and neurotrophic factors [141], and a further in vivo study in mice demonstrated that conditioned medium of IL- $1 \alpha$-primed MSCs administered peripherally after stroke had beneficial effects on stroke outcome and functional recovery [139]. Further work investigating the efficacy of targeted delivery of IL- $1 \alpha$-primed MSCs in stroke is ongoing. 


\section{Conclusion and Future Therapeutic Perspective}

Stroke affects millions of people every year. With the world populations steadily rising, the global burden of stroke keeps rising proportionally. As a result, there remains a global and critical need to develop better treatment options. Strokeinduced neurogenesis presents a promising therapeutic target, since it can allow the brain to, essentially, rewire and refresh itself, and heal the damage caused by the ischemia or hemorrhage. However, harnessing neurogenesis remains a challenge because of the intricate interplay of the factors involved, especially ones involved in neuroinflammation. It is now well understood that the two processes much more deeply connected than a simple inverse relationship. Moreover, both processes are interconnected with angiogenesis and together work towards post-stroke brain repair. In order to harness them and improve functional recovery, it is imperative, now more than ever, to characterize the roles played by each immune cell, cytokine, and chemokine, as part of the post-injury microenvironment, taking into special consideration their temporal expression patterns, specific effects on angiogenesis, neurogenesis, neuroprotection, and neuron elimination. All of these need to be considered carefully to craft effective therapeutic cocktails that are to achieve maximum treatment efficiency.

Author Contributions A.R., N.A., and E.P. performed literature searches and drafted the literature review. A.R., N.A., E.P., and G.J.B. revised and finalized the manuscript. All authors have read and agreed to the published version of the manuscript.

Funding National Institutes of Health Grant number R01NS089515 awarded to G.J.B and R01NS101752 awarded to G.J.B and E.P.

\section{Compliance with Ethical Standards}

Conflict of Interest The authors declare that they have no conflict of interest.

Ethics Approval This article does not contain any studies with human participants or animals performed by any of the authors.

Consent to Participate This article does not contain any studies with human participants and therefore did not require any consent to participate.

Consent for Publication All authors consent to the publication of this manuscript. Consent letters can be obtained from the corresponding author upon reasonable request.

Open Access This article is licensed under a Creative Commons Attribution 4.0 International License, which permits use, sharing, adaptation, distribution and reproduction in any medium or format, as long as you give appropriate credit to the original author(s) and the source, provide a link to the Creative Commons licence, and indicate if changes were made. The images or other third party material in this article are included in the article's Creative Commons licence, unless indicated otherwise in a credit line to the material. If material is not included in the article's Creative Commons licence and your intended use is not permitted by statutory regulation or exceeds the permitted use, you will need to obtain permission directly from the copyright holder. To view a copy of this licence, visit http://creativecommons.org/licenses/by/4.0/.

\section{References}

1. Ojaghihaghighi S, Vahdati SS, Mikaeilpour A, Ramouz A. Comparison of neurological clinical manifestation in patients with hemorrhagic and ischemic stroke. World J Emerg Med. 2017;8(1):34-8. https://doi.org/10.5847/wjem.j.1920-8642.2017. 01.006 .

2. Jayaraj RL, Azimullah S, Beiram R, Jalal FY, Rosenberg GA. Neuroinflammation: friend and foe for ischemic stroke. J Neuroinflammation. 2019;16(1):142. https://doi.org/10.1186/ s12974-019-1516-2.

3. Prabhakaran S, Ruff I, Bernstein RA. Acute stroke intervention: a systematic review. JAMA. 2015;313(14):1451-62. https://doi. org/10.1001/jama.2015.3058.

4. Dorado L, Millan M, Davalos A. Reperfusion therapies for acute ischemic stroke: an update. Curr Cardiol Rev. 2014;10(4):327-35. https://doi.org/10.2174/1573403x10666140320144637.

5. Fan L, Zhang CJ, Zhu L, Chen J, Zhang Z, Liu P, et al. FasLPDPK1 pathway promotes the cytotoxicity of CD8(+) T cells during ischemic stroke. Transl Stroke Res. 2020;11:747-61. https://doi.org/10.1007/s12975-019-00749-0.

6. Jin K, Wang X, Xie L, Mao XO, Zhu W, Wang Y, et al. Evidence for stroke-induced neurogenesis in the human brain. Proc Natl Acad Sci U S A. 2006;103:13198-202. https://doi.org/10.1073/ pnas.0603512103.

7. Thored P, Arvidsson A, Cacci E, Ahlenius H, Kallur T, Darsalia $\mathrm{V}$, et al. Persistent production of neurons from adult brain stem cells during recovery after stroke. Stem Cells. 2006;24(3):739-47. https://doi.org/10.1634/stemcells.2005-0281.

8. Darsalia V, Heldmann U, Lindvall O, Kokaia Z. Stroke-induced neurogenesis in aged brain. Stroke. 2005;36(8):1790-5. https:// doi.org/10.1161/01.STR.0000173151.36031.be.

9. Nygren J, Wieloch T, Pesic J, Brundin P, Deierborg T. Enriched environment attenuates cell genesis in subventricular zone after focal ischemia in mice and decreases migration of newborn cells to the striatum. Stroke. 2006;37:2824-9. https://doi.org/10.1161/ 01.STR.0000244769.39952.90.

10. Bravo-Ferrer I, Cuartero MI, Zarruk JG, Pradillo JM, Hurtado O, Romera VG, et al. Cannabinoid type-2 receptor drives neurogenesis and improves functional outcome after stroke. Stroke. 2017;48:204-12. https://doi.org/10.1161/STROKEAHA. 116.014793 .

11. Zhang RL, Zhang ZG, Zhang L, Chopp M. Proliferation and differentiation of progenitor cells in the cortex and the subventricular zone in the adult rat after focal cerebral ischemia. Neuroscience. 2001;105:33-41. https://doi.org/10.1016/S0306-4522(01)001178.

12. Tonchev AB, Yamashima T, Zhao L, Okano HJ, Okano H. Proliferation of neural and neuronal progenitors after global brain ischemia in young adult macaque monkeys. Mol Cell Neurosci. 2003;23:292-301. https://doi.org/10.1016/S1044-7431(03) 00058-7.

13. Jin K, Minami M, Lan JQ, Mao XO, Batteur S, Simon RP, et al. Neurogenesis in dentate subgranular zone and rostral subventricular zone after focal cerebral ischemia in the rat. Proc 
Natl Acad Sci U S A. 2001;98:4710-5. https://doi.org/10.1073/ pnas.081011098.

14. Jin K, Sun Y, Xie L, Peel A, Mao XO, Batteur S, et al. Directed migration of neuronal precursors into the ischemic cerebral cortex and striatum. Mol Cell Neurosci. 2003;24:171-89. https://doi.org/ 10.1016/S1044-7431(03)00159-3.

15. Arvidsson A, Collin T, Kirik D, Kokaia Z, Lindvall O. Neuronal replacement from endogenous precursors in the adult brain after stroke. Nat Med. 2002;8(9):963-70. https://doi.org/10.1038/ $\mathrm{nm} 747$.

16. Zhang R, Zhang Z, Wang L, Wang Y, Gousev A, Zhang L, et al. Activated neural stem cells contribute to stroke-induced neurogenesis and neuroblast migration toward the infarct boundary in adult rats. J Cereb Blood Flow Metab. 2004;24(4):441-8. https://doi.org/10.1097/00004647-200404000-00009.

17. Salmeron KE, Maniskas ME, Edwards DN, Wong R, Rajkovic I, Trout A, et al. Interleukin 1 alpha administration is neuroprotective and neuro-restorative following experimental ischemic stroke. J Neuroinflammation. 2019;16(1):222. https://doi.org/10.1186/ s12974-019-1599-9.

18. Kiyota T, Ingraham KL, Swan RJ, Jacobsen MT, Andrews SJ, Ikezu T. AAV serotype 2/1-mediated gene delivery of antiinflammatory interleukin-10 enhances neurogenesis and cognitive function in APPPS1 mice. Gene Ther. 2012;19:724-33. https:// doi.org/10.1038/gt.2011.126.

19. Seki T, Arai Y. Age-related production of new granule cells in the adult dentate gyrus. NeuroReport. 1995;6:2479-82. https://doi. org/10.1097/00001756-199512150-00010.

20. Valliéres L, Campbell IL, Gage FH, Sawchenko PE. Reduced hippocampal neurogenesis in adult transgenic mice with chronic astrocytic production of interleukin-6. J Neurosci. 2002;22:48692. https://doi.org/10.1523/jneurosci.22-02-00486.2002.

21. Temple S. The development of neural stem cells. Nature. 2001;414(6859):112-7. https://doi.org/10.1038/35102174.

22. Lois C, Alvarez-Buylla A. Proliferating subventricular zone cells in the adult mammalian forebrain can differentiate into neurons and glia. Proc Natl Acad Sci U S A. 1993;90(5):2074-7. https:// doi.org/10.1073/pnas.90.5.2074.

23. Reynolds BA, Weiss S. Generation of neurons and astrocytes from isolated cells of the adult mammalian central nervous system. Science. 1992;255(5052):1707-10. https://doi.org/10.1126/ science. 1553558 .

24. Ruan L, Wang B, ZhuGe Q, Jin K. Coupling of neurogenesis and angiogenesis after ischemic stroke. Brain Res. 2015;1623:166-73. https://doi.org/10.1016/j.brainres.2015.02.042.

25. Ikeda N, Nonoguchi N, Zhao MZ, Watanabe T, Kajimoto Y, Furutama D, et al. Bone marrow stromal cells that enhanced fibroblast growth factor-2 secretion by herpes simplex virus vector improve neurological outcome after transient focal cerebral ischemia in rats. Stroke. 2005;36(12):2725-30. https://doi.org/10.1161/ 01.STR.0000190006.88896.d3.

26. Yoshimura S, Takagi Y, Harada J, Teramoto T, Thomas SS, Waeber C, et al. FGF-2 regulation of neurogenesis in adult hippocampus after brain injury. Proc Natl Acad Sci U S A. 2001;98(10):5874-9. https://doi.org/10.1073/pnas.101034998.

27. Yan YP, Sailor KA, Vemuganti R, Dempsey RJ. Insulin-like growth factor-1 is an endogenous mediator of focal ischemiainduced neural progenitor proliferation. Eur J Neurosci. 2006;24(1):45-54. https://doi.org/10.1111/j.1460-9568.2006. 04872.x.

28. Zhu W, Fan Y, Hao Q, Shen F, Hashimoto T, Yang GY, et al. Postischemic IGF-1 gene transfer promotes neurovascular regeneration after experimental stroke. J Cereb Blood Flow Metab. 2009;29(9):1528-37. https://doi.org/10.1038/jcbfm.2009.75.

29. Andsberg G, Kokaia Z, Klein RL, Muzyczka N, Lindvall O, Mandel RJ. Neuropathological and behavioral consequences of adeno-associated viral vector-mediated continuous intrastriatal neurotrophin delivery in a focal ischemia model in rats. Neurobiol Dis. 2002;9(2):187-204. https://doi.org/10.1006/nbdi. 2001.0456

30. Kokaia Z, Andsberg G, Yan Q, Lindvall O. Rapid alterations of BDNF protein levels in the rat brain after focal ischemia: evidence for increased synthesis and anterograde axonal transport. Exp Neurol. 1998;154(2):289-301. https://doi.org/10.1006/exnr. 1998.6888

31. Chen J, Zacharek A, Zhang C, Jiang H, Li Y, Roberts C, et al. Endothelial nitric oxide synthase regulates brain-derived neurotrophic factor expression and neurogenesis after stroke in mice. $\mathrm{J}$ Neurosci. 2005;25(9):2366-75. https://doi.org/10.1523/ JNEUROSCI.5071-04.2005.

32. Jin K, Zhu Y, Sun Y, Mao XO, Xie L, Greenberg DA. Vascular endothelial growth factor (VEGF) stimulates neurogenesis in vitro and in vivo. Proc Natl Acad Sci U S A. 2002;99(18):11946-50. https://doi.org/10.1073/pnas.182296499.

33. Ohab JJ, Fleming S, Blesch A, Carmichael ST. A neurovascular niche for neurogenesis after stroke. J Neurosci. 2006;26(50): 13007-16. https://doi.org/10.1523/JNEUROSCI.4323-06.2006.

34. Yan YP, Sailor KA, Lang BT, Park SW, Vemuganti R, Dempsey RJ. Monocyte chemoattractant protein-1 plays a critical role in neuroblast migration after focal cerebral ischemia. J Cereb Blood Flow Metab. 2007;27(6):1213-24. https://doi.org/10.1038/sj. jcbfm.9600432.

35. Barkho BZ, Munoz AE, Li X, Li L, Cunningham LA, Zhao X. Endogenous matrix metalloproteinase (MMP)-3 and MMP-9 promote the differentiation and migration of adult neural progenitor cells in response to chemokines. Stem Cells. 2008;26(12):3139 49. https://doi.org/10.1634/stemcells.2008-0519.

36. Wang L, Zhang ZG, Zhang RL, Gregg SR, Hozeska-Solgot A, LeTourneau Y, et al. Matrix metalloproteinase 2 (MMP2) and MMP9 secreted by erythropoietin-activated endothelial cells promote neural progenitor cell migration. J Neurosci. 2006;26(22): 5996-6003. https://doi.org/10.1523/JNEUROSCI.5380-05.2006.

37. Zhang Y, Zhang H, Lin S, Chen X, Yao Y, Mao X, et al. SDF-1/ CXCR7 chemokine signaling is induced in the peri-infarct regions in patients with ischemic stroke. Aging Dis. 2018;9(2):287-95. https://doi.org/10.14336/AD.2017.1112.

38. Inose Y, Kato Y, Kitagawa K, Uchiyama S, Shibata N. Activated microglia in ischemic stroke penumbra upregulate MCP-1 and CCR2 expression in response to lysophosphatidylcholine derived from adjacent neurons and astrocytes. Neuropathology. 2015;35(3):209-23. https://doi.org/10.1111/neup.12182.

39. Garcia-Vilas JA, Quesada AR, Medina MA. Hydroxytyrosol targets extracellular matrix remodeling by endothelial cells and inhibits both ex vivo and in vivo angiogenesis. Food Chem. 2017;221:1741-6. https://doi.org/10.1016/j.foodchem.2016.10. 111.

40. Roberts J, Kahle MP, Bix GJ. Perlecan and the blood-brain barrier: beneficial proteolysis? Front Pharmacol. 2012;3:155. https:// doi.org/10.3389/fphar.2012.00155.

41. Lee B, Clarke D, Al Ahmad A, Kahle M, Parham C, Auckland L, et al. Perlecan domain $\mathrm{V}$ is neuroprotective and proangiogenic following ischemic stroke in rodents. J Clin Invest. 2011;121(8): 3005-23. https://doi.org/10.1172/JCI46358.

42. Trout AL, Kahle MP, Roberts JM, Marcelo A, de Hoog L, Boychuk JA, et al. Perlecan domain-V enhances neurogenic brain repair after stroke in mice. Transl Stroke Res. 2020. https://doi. org/10.1007/s12975-020-00800-5.

43. Bae CS, Song J. The role of glucagon-like peptide 1 (GLP1) in type 3 diabetes: GLP-1 controls insulin resistance, neuroinflammation and neurogenesis in the brain. Int J Mol Sci. 2017;18. https://doi.org/10.3390/ijms 18112493. 
44. Burg N, Bittner S, Ellwardt E. Role of the epigenetic factor Sirt7 in neuroinflammation and neurogenesis. Neurosci Res. 2018;131:19. https://doi.org/10.1016/j.neures.2017.09.005.

45. Yang B, Figueroa DM, Hou Y, Babbar M, Baringer SL, Croteau DL, et al. NEIL1 stimulates neurogenesis and suppresses neuroinflammation after stress. Free Radic Biol Med. 2019;141:47-58. https://doi.org/10.1016/j.freeradbiomed.2019.05.037.

46. Wang LL, Li J, Gu X, Wei L, Yu SP. Delayed treatment of 6Bromoindirubin-3'-oxime stimulates neurogenesis and functional recovery after focal ischemic stroke in mice. Int J Dev Neurosci. 2017;57:77-84. https://doi.org/10.1016/j.ijdevneu.2017.01.002.

47. Zheng J, Liu Z, Li W, Tang J, Zhang D, Tang X. Lithium posttreatment confers neuroprotection through glycogen synthase kinase- $3 \beta$ inhibition in intracerebral hemorrhage rats. $\mathrm{J}$ Neurosurg. 2017;127:716-24. https://doi.org/10.3171/2016.7. JNS152995.

48. Zhao S, Liu Z, Yu Z, Wu X, Li R, Tang X. BIO alleviates inflammation through inhibition of GSK-3 $\beta$ in a rat model of intracerebral hemorrhage. J Neurosurg. 2019:1-9. https://doi.org/10.3171/ 2019.4.jns 183501 .

49. Islam O, Gong X, Rose-John S, Heese K. Interleukin-6 and neural stem cells: more than gliogenesis. Mol Biol Cell. 2009;20:188-99. https://doi.org/10.1091/mbc.E08-05-0463.

50. Sung PS, Lin PY, Liu CH, Su HC, Tsai KJ. Neuroinflammation and neurogenesis in Alzheimer's disease and potential therapeutic approaches. Int J Mol Sci. 2020;21. https://doi.org/10.3390/ ijms21030701.

51. Greco SJ, Rameshwar P. Enhancing effect of IL-1alpha on neurogenesis from adult human mesenchymal stem cells: implication for inflammatory mediators in regenerative medicine. $\mathrm{J}$ Immunol. 2007;179(5):3342-50. https://doi.org/10.4049/ jimmunol.179.5.3342.

52. Rider P, Carmi Y, Guttman O, Braiman A, Cohen I, Voronov E, et al. IL- $1 \alpha$ and IL- $1 \beta$ recruit different myeloid cells and promote different stages of sterile inflammation. J Immunol. 2011;187: 4835-43. https://doi.org/10.4049/jimmunol.1102048.

53. Luheshi NM, Kovacs KJ, Lopez-Castejon G, Brough D, Denes A. Interleukin-1alpha expression precedes IL-1beta after ischemic brain injury and is localised to areas of focal neuronal loss and penumbral tissues. J Neuroinflammation. 2011;8:186. https://doi. org/10.1186/1742-2094-8-186.

54. Ajmone-Cat MA, Cacci E, Ragazzoni Y, Minghetti L, Biagioni S. Pro-gliogenic effect of IL-1alpha in the differentiation of embryonic neural precursor cells in vitro. J Neurochem. 2010;113(4): 1060-72. https://doi.org/10.1111/j.1471-4159.2010.06670.x.

55. Wu MD, Montgomery SL, Rivera-Escalera F, Olschowka JA, O'Banion MK. Sustained IL-1beta expression impairs adult hippocampal neurogenesis independent of IL-1 signaling in nestin+ neural precursor cells. Brain Behav Immun. 2013;32:9-18. https:// doi.org/10.1016/j.bbi.2013.03.003.

56. Wang X, Fu S, Wang Y, Yu P, Hu J, Gu W, et al. Interleukin- $1 \beta$ mediates proliferation and differentiation of multipotent neural precursor cells through the activation of SAPK/JNK pathway. Mol Cell Neurosci. 2007;36:343-54. https://doi.org/10.1016/j. men.2007.07.005.

57. Green HF, Treacy E, Keohane AK, Sullivan AM, O'Keeffe GW, Nolan YM. A role for interleukin-1beta in determining the lineage fate of embryonic rat hippocampal neural precursor cells. Mol Cell Neurosci. 2012;49(3):311-21. https://doi.org/10.1016/j.mcn. 2012.01.001.

58. Rodriguez-Grande B, Swana M, Nguyen L, Englezou P, Maysami S, Allan SM, et al. The acute-phase protein PTX3 is an essential mediator of glial scar formation and resolution of brain edema after ischemic injury. J Cereb Blood Flow Metab. 2014;34(3): 480-8. https://doi.org/10.1038/jcbfm.2013.224.
59. Rodriguez-Grande B, Varghese L, Molina-Holgado F, Rajkovic $\mathrm{O}$, Garlanda C, Denes A, et al. Pentraxin 3 mediates neurogenesis and angiogenesis after cerebral ischaemia. J Neuroinflammation. 2015;12:15. https://doi.org/10.1186/s12974-014-0227-y.

60. Morgan SC, Taylor DL, Pocock JM. Microglia release activators of neuronal proliferation mediated by activation of mitogenactivated protein kinase, phosphatidylinositol-3-kinase/ Akt and delta-Notch signalling cascades. J Neurochem. 2004;90:89-101. https://doi.org/10.1111/j.1471-4159.2004.02461.x.

61. Aarum J, Sandberg K, Haeberlein SL, Persson MA. Migration and differentiation of neural precursor cells can be directed by microglia. Proc Natl Acad Sci U S A. 2003;100(26):15983-8. https://doi. org/10.1073/pnas.2237050100.

62. Diaz-Aparicio I, Paris I, Sierra-Torre V, Plaza-Zabala A, Rodríguez-Iglesias N, Márquez-Ropero M, et al. Microglia actively remodel adult hippocampal neurogenesis through the phagocytosis secretome. J Neurosci. 2020;40:1453-82. https:// doi.org/10.1523/JNEUROSCI.0993-19.2019.

63. Sierra A, Encinas JM, Deudero JJP, Chancey JH, Enikolopov G, Overstreet-Wadiche LS, et al. Microglia shape adult hippocampal neurogenesis through apoptosis-coupled phagocytosis. Cell Stem Cell. 2010;7:483-95. https://doi.org/10.1016/j.stem.2010.08.014.

64. Walton NM, Sutter BM, Laywell ED, Levkoff LH, Kearns SM, Marshall GP 2nd, et al. Microglia instruct subventricular zone neurogenesis. Glia. 2006;54(8):815-25. https://doi.org/10.1002/ glia.20419.

65. Szalay G, Martinecz B, Lenart N, Kornyei Z, Orsolits B, Judak L, et al. Microglia protect against brain injury and their selective elimination dysregulates neuronal network activity after stroke. Nat Commun. 2016;7:11499. https://doi.org/10.1038/ ncomms 11499.

66. Reshef R, Kreisel T, Beroukhim Kay D, Yirmiya R. Microglia and their CX3CR1 signaling are involved in hippocampal- but not olfactory bulb-related memory and neurogenesis. Brain Behav Immun. 2014. https://doi.org/10.1016/j.bbi.2014.04.009.

67. Bachstetter AD, Morganti JM, Jernberg J, Schlunk A, Mitchell $\mathrm{SH}$, Brewster KW, et al. Fractalkine and CX 3CR1 regulate hippocampal neurogenesis in adult and aged rats. Neurobiol Aging. 2011;32:2030-44. https://doi.org/10.1016/j.neurobiolaging.2009. 11.022 .

68. Mori T, Buffo A, Götz M. The novel roles of glial cells revisited: the contribution of radial glia and astrocytes to neurogenesis. Curr Top Dev Biol. 2005;69:67-99.

69. Magnusson JP, Frisén J. Stars from the darkest night: unlocking the neurogenic potential of astrocytes in different brain regions. Development. 2016;143(7):1075-86.

70. Becerra-Calixto A, Cardona-Gómez GP. The role of astrocytes in neuroprotection after brain stroke: potential in cell therapy. Front Mol Neurosci. 2017;10:88.

71. Götz M, Sirko S, Beckers J, Irmler M. Reactive astrocytes as neural stem or progenitor cells: in vivo lineage, in vitro potential, and genome-wide expression analysis. Glia. 2015;63(8):1452-68.

72. Laywell ED, Rakic P, Kukekov VG, Holland EC, Steindler DA. Identification of a multipotent astrocytic stem cell in the immature and adult mouse brain. Proc Natl Acad Sci. 2000;97(25):13883-8.

73. Seri B, Garcia-Verdugo JM, McEwen BS, Alvarez-Buylla A. Astrocytes give rise to new neurons in the adult mammalian hippocampus. J Neurosci. 2001;21(18):7153-60.

74. Corti S, Nizzardo M, Simone C, Falcone M, Donadoni C, Salani $\mathrm{S}$, et al. Direct reprogramming of human astrocytes into neural stem cells and neurons. Exp Cell Res. 2012;318(13):1528-41.

75. Faiz M, Sachewsky N, Gascón S, Bang KA, Morshead CM, Nagy A. Adult neural stem cells from the subventricular zone give rise to reactive astrocytes in the cortex after stroke. Cell Stem Cell. 2015;17(5):624-34. 
76. Zhang Y, Xu D, Qi H, Yuan Y, Liu H, Yao S, et al. Enriched environment promotes post-stroke neurogenesis through NF-kBmediated secretion of IL-17A from astrocytes. Brain Res. 2018;1687:20-31.

77. Tao Y, Ma L, Liao Z, Le Q, Yu J, Liu X, et al. Astroglial $\beta$ arrestin1-mediated nuclear signaling regulates the expansion of neural precursor cells in adult hippocampus. Sci Rep. 2015;5: 15506.

78. Terrillion CE, Abazyan B, Yang Z, Crawford J, Shevelkin AV, Jouroukhin Y, et al. DISC1 in astrocytes influences adult neurogenesis and hippocampus-dependent behaviors in mice. Neuropsychopharmacology. 2017;42(11):2242-51.

79. Jin K, Wang X, Xie L, Mao XO, Greenberg DA. Transgenic ablation of doublecortin-expressing cells suppresses adult neurogenesis and worsens stroke outcome in mice. Proc Natl Acad Sci U S A. 2010;107(17):7993-8. https://doi.org/10.1073/ pnas. 1000154107.

80. Sun C, Sun $\mathrm{H}, \mathrm{Wu}$ S, Lee CC, Akamatsu Y, Wang RK, et al. Conditional ablation of neuroprogenitor cells in adult mice impedes recovery of poststroke cognitive function and reduces synaptic connectivity in the perforant pathway. J Neurosci. 2013;33(44):17314-25. https://doi.org/10.1523/JNEUROSCI. 2129-13.2013.

81. Sun F, Wang X, Mao X, Xie L, Jin K. Ablation of neurogenesis attenuates recovery of motor function after focal cerebral ischemia in middle-aged mice. PLoS One. 2012;7(10):e46326. https://doi. org/10.1371/journal.pone.0046326.

82. Hao XZ, Yin LK, Tian JQ, Li CC, Feng XY, Yao ZW, et al. Inhibition of Notch1 signaling at the subacute stage of stroke promotes endogenous neurogenesis and motor recovery after stroke. Front Cell Neurosci. 2018;12:245. https://doi.org/10. 3389/fncel.2018.00245.

83. Kim H, Wei Y, Lee JY, Wu Y, Zheng Y, Moskowitz MA, et al. Myeloperoxidase inhibition increases neurogenesis after ischemic stroke. J Pharmacol Exp Ther. 2016;359(2):262-72. https://doi. org/10.1124/jpet.116.235127.

84. Wang Z, Yuan Y, Zhang Z, Ding K. Inhibition of miRNA-27b enhances neurogenesis via AMPK activation in a mouse ischemic stroke model. FEBS Open Biol. 2019;9(5):859-69. https://doi. org/10.1002/2211-5463.12614.

85. Chen D, Wei L, Liu ZR, Yang JJ, Gu X, Wei ZZ, et al. Pyruvate kinase M2 increases angiogenesis, neurogenesis, and functional recovery mediated by upregulation of STAT3 and focal adhesion kinase activities after ischemic stroke in adult mice. Neurotherapeutics. 2018;15(3):770-84. https://doi.org/10.1007/ s13311-018-0635-2.

86. Koh SH, Park HH. Neurogenesis in stroke recovery. Transl Stroke Res. 2017;8(1):3-13. https://doi.org/10.1007/s12975-016-0460-z.

87. Lu J, Manaenko A, Hu Q. Targeting adult neurogenesis for poststroke therapy. Stem Cells Int. 2017;2017:5868632-10. https://doi.org/10.1155/2017/5868632.

88. Marques BL, Carvalho GA, Freitas EMM, Chiareli RA, Barbosa TG, Di Araujo AGP, et al. The role of neurogenesis in neurorepair after ischemic stroke. Semin Cell Dev Biol. 2019;95:98-110. https://doi.org/10.1016/j.semcdb.2018.12.003.

89. Liu J, Solway K, Messing RO, Sharp FR. Increased neurogenesis in the dentate gyrus after transient global ischemia in gerbils. J Neurosci. 1998;18(19):7768-78.

90. Kreuzberg M, Kanov E, Timofeev O, Schwaninger M, Monyer H, Khodosevich K. Increased subventricular zone-derived cortical neurogenesis after ischemic lesion. Exp Neurol. 2010;226(1):90 9. https://doi.org/10.1016/j.expneurol.2010.08.006.

91. Parent JM, Vexler ZS, Gong C, Derugin N, Ferriero DM. Rat forebrain neurogenesis and striatal neuron replacement after focal stroke. Ann Neurol. 2002;52(6):802-13. https://doi.org/10.1002/ ana.10393.
92. Belayev L, Hong SH, Menghani H, Marcell SJ, Obenaus A, Freitas RS, et al. Docosanoids promote neurogenesis and angiogenesis, blood-brain barrier integrity, penumbra protection, and neurobehavioral recovery after experimental ischemic stroke. Mol Neurobiol. 2018;55(8):7090-106. https://doi.org/10.1007/ s12035-018-1136-3.

93. Li C, Zhang B, Zhu Y, Li Y, Liu P, Gao B, et al. Post-stroke constraint-induced movement therapy increases functional recovery, angiogenesis, and neurogenesis with enhanced expression of HIF-1alpha and VEGF. Curr Neurovasc Res. 2017;14(4):368-77. https://doi.org/10.2174/1567202614666171128120558.

94. Madelaine R, Sloan SA, Huber N, Notwell JH, Leung LC, Skariah $\mathrm{G}$, et al. MicroRNA-9 couples brain neurogenesis and angiogenesis. Cell Rep. 2017;20(7):1533-42. https://doi.org/10.1016/j. celrep.2017.07.051.

95. Zhang SJ, Wang RL, Zhao HP, Tao Z, Li JC, Ju F, et al. MEPO promotes neurogenesis and angiogenesis but suppresses gliogenesis in mice with acute ischemic stroke. Eur J Pharmacol. 2019;849:1-10. https://doi.org/10.1016/j.ejphar.2019.01.066.

96. Carmeliet P, Jain RK. Molecular mechanisms and clinical applications of angiogenesis. Nature. 2011;473(7347):298-307. https://doi.org/10.1038/nature10144.

97. Risau W. Mechanisms of angiogenesis. Nature. 1997;386(6626): 671-4. https://doi.org/10.1038/386671a0.

98. Shen Q, Goderie SK, Jin L, Karanth N, Sun Y, Abramova N, et al. Endothelial cells stimulate self-renewal and expand neurogenesis of neural stem cells. Science. 2004;304(5675):1338-40. https:// doi.org/10.1126/science.1095505.

99. Teng H, Zhang ZG, Wang L, Zhang RL, Zhang L, Morris D, et al. Coupling of angiogenesis and neurogenesis in cultured endothelial cells and neural progenitor cells after stroke. J Cereb Blood Flow Metab. 2008;28(4):764-71. https://doi.org/10.1038/sj.jcbfm. 9600573.

100. Hayashi T, Noshita N, Sugawara T, Chan PH. Temporal profile of angiogenesis and expression of related genes in the brain after ischemia. J Cereb Blood Flow Metab. 2003;23(2):166-80. https://doi.org/10.1097/01.WCB.0000041283.53351.CB.

101. Beck H, Acker T, Wiessner C, Allegrini PR, Plate KH. Expression of angiopoietin-1, angiopoietin-2, and tie receptors after middle cerebral artery occlusion in the rat. Am J Pathol. 2000;157(5): 1473-83. https://doi.org/10.1016/S0002-9440(10)64786-4.

102. Beck H, Plate KH. Angiogenesis after cerebral ischemia. Acta Neuropathol. 2009;117(5):481-96. https://doi.org/10.1007/ s00401-009-0483-6.

103. Marti HJ, Bernaudin M, Bellail A, Schoch H, Euler M, Petit E, et al. Hypoxia-induced vascular endothelial growth factor expression precedes neovascularization after cerebral ischemia. Am J Pathol. 2000;156(3):965-76. https://doi.org/10.1016/S00029440(10)64964-4.

104. Chopp M, Li Y. Treatment of neural injury with marrow stromal cells. Lancet Neurol. 2002;1(2):92-100. https://doi.org/10.1016/ s1474-4422(02)00040-6.

105. Wang L, Zhang Z, Wang Y, Zhang R, Chopp M. Treatment of stroke with erythropoietin enhances neurogenesis and angiogenesis and improves neurological function in rats. Stroke. 2004;35(7): 1732-7. https://doi.org/10.1161/01.STR.0000132196.49028.a4.

106. Shyu WC, Lin SZ, Yang HI, Tzeng YS, Pang CY, Yen PS, et al. Functional recovery of stroke rats induced by granulocyte colonystimulating factor-stimulated stem cells. Circulation. 2004;110(13):1847-54. https://doi.org/10.1161/01.CIR. 0000142616.07367 .66 .

107. Taguchi A, Soma T, Tanaka H, Kanda T, Nishimura H, Yoshikawa $\mathrm{H}$, et al. Administration of CD34+ cells after stroke enhances neurogenesis via angiogenesis in a mouse model. J Clin Invest. 2004;114(3):330-8. https://doi.org/10.1172/JCI20622. 
108. Chen J, Zhang ZG, Li Y, Wang Y, Wang L, Jiang H, et al. Statins induce angiogenesis, neurogenesis, and synaptogenesis after stroke. Ann Neurol. 2003;53(6):743-51. https://doi.org/10.1002/ ana.10555.

109. Yrjanheikki J, Tikka T, Keinanen R, Goldsteins G, Chan PH, Koistinaho J. A tetracycline derivative, minocycline, reduces inflammation and protects against focal cerebral ischemia with a wide therapeutic window. Proc Natl Acad Sci U S A. 1999;96(23):13496-500. https://doi.org/10.1073/pnas.96.23. 13496.

110. Yew WP, Djukic ND, Jayaseelan JSP, Walker FR, Roos KAA, Chataway TK, et al. Early treatment with minocycline following stroke in rats improves functional recovery and differentially modifies responses of peri-infarct microglia and astrocytes. J Neuroinflammation. 2019;16(1):6. https://doi.org/10.1186/ s12974-018-1379-y.

111. Giri PK, Lu Y, Lei S, Li W, Zheng J, Lu H, et al. Pretreatment with minocycline improves neurogenesis and behavior performance after midazolam exposure in neonatal rats. Neuroreport. 2018;29(3):153-9. https://doi.org/10.1097/WNR. 0000000000000937.

112. Inta D, Lang UE, Borgwardt S, Meyer-Lindenberg A, Gass P. Microglia activation and schizophrenia: lessons from the effects of minocycline on postnatal neurogenesis, neuronal survival and synaptic pruning. Schizophr Bull. 2017;43(3):493-6. https://doi. org $/ 10.1093 / \mathrm{schbul} / \mathrm{sbw} 088$.

113. Wadhwa M, Prabhakar A, Ray K, Roy K, Kumari P, Jha PK, et al. Inhibiting the microglia activation improves the spatial memory and adult neurogenesis in rat hippocampus during $48 \mathrm{~h}$ of sleep deprivation. J Neuroinflammation. 2017;14(1):222. https://doi. org/10.1186/s12974-017-0998-z.

114. Padma Srivastava MV, Bhasin A, Bhatia R, Garg A, Gaikwad S, Prasad K, et al. Efficacy of minocycline in acute ischemic stroke: a single-blinded, placebo-controlled trial. Neurol India. 2012;60(1): 23-8. https://doi.org/10.4103/0028-3886.93584.

115. Malhotra K, Chang JJ, Khunger A, Blacker D, Switzer JA, Goyal $\mathrm{N}$, et al. Minocycline for acute stroke treatment: a systematic review and meta-analysis of randomized clinical trials. J Neurol. 2018;265(8):1871-9. https://doi.org/10.1007/s00415-018-89353.

116. Engels J, Elting N, Braun L, Bendix I, Herz J, Felderhoff-Muser $\mathrm{U}$, et al. Sildenafil enhances quantity of immature neurons and promotes functional recovery in the developing ischemic mouse brain. Dev Neurosci. 2017;39(1-4):287-97. https://doi.org/10. $1159 / 000457832$

117. Zhang R, Wang Y, Zhang L, Zhang Z, Tsang W, Lu M, et al. Sildenafil (Viagra) induces neurogenesis and promotes functional recovery after stroke in rats. Stroke. 2002;33(11):2675-80. https:// doi.org/10.1161/01.str.0000034399.95249.59.

118. Zhang RL, Chopp M, Roberts C, Wei M, Wang X, Liu X, et al. Sildenafil enhances neurogenesis and oligodendrogenesis in ischemic brain of middle-aged mouse. PLoS One. 2012;7(10): e48141. https://doi.org/10.1371/journal.pone.0048141.

119. Zhang RL, Zhang Z, Zhang L, Wang Y, Zhang C, Chopp M. Delayed treatment with sildenafil enhances neurogenesis and improves functional recovery in aged rats after focal cerebral ischemia. J Neurosci Res. 2006;83(7):1213-9. https://doi.org/10.1002/ jnr.20813.

120. Cheng Y, Pardo M, Armini RS, Martinez A, Mouhsine H, Zagury $\mathrm{JF}$, et al. Stress-induced neuroinflammation is mediated by GSK3dependent TLR4 signaling that promotes susceptibility to depression-like behavior. Brain Behav Immun. 2016;53:207-22. https://doi.org/10.1016/j.bbi.2015.12.012.

121. Vallee A, Lecarpentier Y, Guillevin R, Vallee JN. Effects of cannabidiol interactions with $\mathrm{Wnt} /$ beta-catenin pathway and PPARgamma on oxidative stress and neuroinflammation in
Alzheimer's disease. Acta Biochim Biophys Sin Shanghai. 2017;49(10):853-66. https://doi.org/10.1093/abbs/gmx073.

122. Lovestone S, Boada M, Dubois B, Hull M, Rinne JO, Huppertz $\mathrm{HJ}$, et al. A phase II trial of tideglusib in Alzheimer's disease. J Alzheimers Dis. 2015;45(1):75-88. https://doi.org/10.3233/JAD141959.

123. Tolosa E, Litvan I, Hoglinger GU, Burn D, Lees A, Andres MV, et al. A phase 2 trial of the GSK-3 inhibitor tideglusib in progressive supranuclear palsy. Mov Disord. 2014;29(4):470-8. https:// doi.org/10.1002/mds.25824.

124. Li R, Liu Z, Wu X, Yu Z, Zhao S, Tang X. Lithium chloride promoted hematoma resolution after intracerebral hemorrhage through GSK-3beta-mediated pathways-dependent microglia phagocytosis and M2-phenotype differentiation, angiogenesis and neurogenesis in a rat model. Brain Res Bull. 2019;152:11727. https://doi.org/10.1016/j.brainresbull.2019.07.019.

125. Emsley HC, Smith CJ, Georgiou RF, Vail A, Hopkins SJ, Rothwell NJ, et al. A randomised phase II study of interleukin-1 receptor antagonist in acute stroke patients. J Neurol Neurosurg Psychiatry. 2005;76(10):1366-72. https://doi.org/10.1136/jnnp. 2004.054882.

126. Smith CJ, Hulme S, Vail A, Heal C, Parry-Jones AR, Scarth S, et al. SCIL-STROKE (Subcutaneous Interleukin-1 Receptor Antagonist in Ischemic Stroke): a randomized controlled phase 2 trial. Stroke. 2018;49(5):1210-6. https://doi.org/10.1161/ STROKEAHA.118.020750.

127. Pradillo JM, Murray KN, Coutts GA, Moraga A, Oroz-Gonjar F, Boutin H, et al. Reparative effects of interleukin-1 receptor antagonist in young and aged/co-morbid rodents after cerebral ischemia. Brain Behav Immun. 2017;61:117-26. https://doi.org/10. 1016/j.bbi.2016.11.013

128. Bernstock JD, Peruzzotti-Jametti L, Ye D, Gessler FA, Maric D, Vicario N, et al. Neural stem cell transplantation in ischemic stroke: a role for preconditioning and cellular engineering. $\mathrm{J}$ Cereb Blood Flow Metab. 2017;37(7):2314-9. https://doi.org/10. 1177/0271678X17700432.

129. Boese AC, Eckert A, Hamblin MH, Lee JP. Human neural stem cells improve early stage stroke outcome in delayed tissue plasminogen activator-treated aged stroke brains. Exp Neurol. 2020;329:113275. https://doi.org/10.1016/j.expneurol.2020. 113275.

130. Boese AC, Le QE, Pham D, Hamblin MH, Lee JP. Neural stem cell therapy for subacute and chronic ischemic stroke. Stem Cell Res Ther. 2018;9(1):154. https://doi.org/10.1186/s13287-0180913-2.

131. Huang L, Wong S, Snyder EY, Hamblin MH, Lee JP. Human neural stem cells rapidly ameliorate symptomatic inflammation in early-stage ischemic-reperfusion cerebral injury. Stem Cell Res Ther. 2014;5(6):129. https://doi.org/10.1186/scrt519.

132. Oki K, Tatarishvili J, Wood J, Koch P, Wattananit S, Mine Y, et al. Human-induced pluripotent stem cells form functional neurons and improve recovery after grafting in stroke-damaged brain. Stem Cells. 2012;30(6):1120-33. https://doi.org/10.1002/stem. 1104.

133. Chen J, Li Y, Wang L, Lu M, Zhang X, Chopp M. Therapeutic benefit of intracerebral transplantation of bone marrow stromal cells after cerebral ischemia in rats. J Neurol Sci. 2001;189(1-2): 49-57. https://doi.org/10.1016/s0022-510x(01)00557-3.

134. Chen J, Li Y, Wang L, Zhang Z, Lu D, Lu M, et al. Therapeutic benefit of intravenous administration of bone marrow stromal cells after cerebral ischemia in rats. Stroke. 2001;32(4):1005-11. https://doi.org/10.1161/01.str.32.4.1005.

135. Tobin MK, Stephen TKL, Lopez KL, Pergande MR, Bartholomew AM, Cologna SM, et al. Activated mesenchymal stem cells induce recovery following stroke via regulation of 
inflammation and oligodendrogenesis. J Am Heart Assoc. 2020;9(7):e013583. https://doi.org/10.1161/JAHA.119.013583.

136. Kalladka D, Sinden J, Pollock K, Haig C, McLean J, Smith W, et al. Human neural stem cells in patients with chronic ischaemic stroke (PISCES): a phase 1, first-in-man study. Lancet. 2016;388(10046):787-96. https://doi.org/10.1016/S01406736(16)30513-X.

137. Prasad K, Sharma A, Garg A, Mohanty S, Bhatnagar S, Johri S, et al. Intravenous autologous bone marrow mononuclear stem cell therapy for ischemic stroke: a multicentric, randomized trial. Stroke. 2014;45(12):3618-24. https://doi.org/10.1161/ STROKEAHA.114.007028.

138. Savitz SI, Yavagal D, Rappard G, Likosky W, Rutledge N, Graffagnino C, et al. A phase 2 randomized, sham-controlled trial of internal carotid artery infusion of autologous bone marrowderived ALD-401 cells in patients with recent stable ischemic stroke (RECOVER-stroke). Circulation. 2019;139(2):192-205. https://doi.org/10.1161/CIRCULATIONAHA.117.030659.

139. Cunningham CJ, Wong R, Barrington J, Tamburrano S, Pinteaux E, Allan SM. Systemic conditioned medium treatment from interleukin-1 primed mesenchymal stem cells promotes recovery after stroke. Stem Cell Res Ther. 2020;11(1):32. https://doi.org/ 10.1186/s13287-020-1560-y.

140. Thomas JM, Cunningham CJ, Lawrence CB, Pinteaux E, Allan SM. Therapeutic potential of extracellular vesicles in preclinical stroke models: a systematic review and meta-analysis. BMJ Open Sci. 2020;4.

141. Redondo-Castro E, Cunningham C, Miller J, Martuscelli L, Aoulad-Ali S, Rothwell NJ, et al. Interleukin-1 primes human mesenchymal stem cells towards an anti-inflammatory and protrophic phenotype in vitro. Stem Cell Res Ther. 2017;8(1):79. https://doi.org/10.1186/s13287-017-0531-4.

142. Chen WC, Chang LH, Huang SS, Huang YJ, Chih CL, Kuo HC, et al. Aryl hydrocarbon receptor modulates stroke-induced astrogliosis and neurogenesis in the adult mouse brain. $\mathrm{J}$
Neuroinflammation. 2019;16(1):187. https://doi.org/10.1186/ s12974-019-1572-7.

143. Cuartero MI, de la Parra J, Perez-Ruiz A, Bravo-Ferrer I, DuranLaforet V, Garcia-Culebras A, et al. Abolition of aberrant neurogenesis ameliorates cognitive impairment after stroke in mice. J Clin Invest. 2019;129(4):1536-50. https://doi.org/10. 1172/JCI120412.

144. Wang YH, Chern CM, Liou KT, Kuo YH, Shen YC. Ergostatrien7,9(11),22-trien-3beta-ol from Antrodia camphorata ameliorates ischemic stroke brain injury via downregulation of p65NFkappa-B and caspase 3, and activation of Akt/GSK3/catenin-associated neurogenesis. Food Funct. 2019;10(8):4725-38. https://doi. org/10.1039/c9fo00908f.

145. Wu X, Liu S, Hu Z, Zhu G, Zheng G, Wang G. Enriched housing promotes post-stroke neurogenesis through calpain 1-STAT3/ HIF-1alpha/VEGF signaling. Brain Res Bull. 2018;139:133-43. https://doi.org/10.1016/j.brainresbull.2018.02.018.

146. Yang L, Tucker D, Dong Y, Wu C, Lu Y, Li Y, et al. Photobiomodulation therapy promotes neurogenesis by improving post-stroke local microenvironment and stimulating neuroprogenitor cells. Exp Neurol. 2018;299(Pt A):86-96. https://doi.org/10.1016/j.expneurol.2017.10.013.

147. Xin H, Katakowski M, Wang F, Qian JY, Liu XS, Ali MM, et al. MicroRNA cluster miR-17-92 cluster in exosomes enhance neuroplasticity and functional recovery after stroke in rats. Stroke. 2017;48(3):747-53. https://doi.org/10.1161/ STROKEAHA.116.015204.

148. Bravo-Ferrer I, Cuartero MI, Zarruk JG, Pradillo JM, Hurtado O, Romera VG, et al. Cannabinoid type-2 receptor drives neurogenesis and improves functional outcome after stroke. Stroke. 2017;48(1):204-12. https://doi.org/10.1161/ STROKEAHA.116.014793.

Publisher's Note Springer Nature remains neutral with regard to jurisdictional claims in published maps and institutional affiliations. 